\title{
OBITUARY
}

\section{CHARLES ERNEST WEST, F.R.C.S.}

Mr. C. E. WEST, consulting aural surgeon to St. Bartholomew's Hospital, died at his home in Budleigh Salterton on January Ist, aged 77 .

Charles Ernest West was educated at Merchant Taylors' School, Crosby, and Balliol College, Oxford, to which he obtained a classical scholarship. $\mathrm{He}$ gained a first in classics and then became interested in science, especially chemistry, and under the tutorship of Sir John Conroy, who had founded the school of chemistry at Balliol, he obtained another first in natural science. He now made up his mind to go in for medicine, and, remaining at Oxford, read anatomy under Arthur Thomson and physiology with Professor Burden Sanderson. He left Balliol in 1897, entering St. Bartholomew's Hospital with the senior open scholarship in science, and next year passed the primary fellowship examination (R.C.S.). He qualified M.R.C.S., L.R.C.P. in I900 and also graduated B.M. His future career was assured when he was awarded the Brackenbury surgical scholarship and Sir George Burrow's prize and was elected house-surgeon to Mr. Alfred Willett, then senior surgeon of the hospital. In 1902 he was admitted F.R.C.S. and was made a junior demonstrator of anatomy, regarded in those days as a probable step to candidature for some future vacancy on the staff. Sir Holburt Waring was head of the anatomical department, and it was no doubt through his initiative that West was encouraged quite early to start specializing in diseases of the ear, rather than follow the course of general surgery.

This was the beginning of a period of renaissance at St. Bartholomew's, which became evident with the re-building of the out-patient department and improvements in the special departments. West was appointed chief assistant to Mr. A. E. Cumberbatch, who for 20 years had been aural surgeon, and he held this appointment for five years before being elected aural surgeon on Mr. Cumberbatch's retirement. Whether in out-patients, in the wards, or in the dissecting-rooms and pathological laboratory, he worked unceasingly with the guidance of Sir Frederick Andrewes and Lord Horder to carry out researches in bacteriology of diseases of the ear, to which hitherto little attention had been given. He published several papers on his personal observations, in the hospital reports and elsewhere. Mr. Cumberbatch, proud of such an enterprising and enthusiastic assistant, encouraged him in every way to gain experience and practice in the surgery of the ear. He developed skill as an outstanding operator, and, as he admitted, he received inspiration from the works of Sir Charles Ballance and Sir William Macewen. Before long practically all patients admitted to the hospital with intracranial infections, if due to ear disease, were referred to the aural department for treatment. He was the new author of "Diseases of the Ear" in Gask's edition of Walsham's Surgery, and was co author, with Mr. Sydney Scott, of a book entitled Operations of 


\section{Obituary}

Aural Surgery, now out of print, written chiefly for house-surgeons and junior specialists. In the Section of Otology of the Royal Society of Medicine he played an active part. Among many contributions was a joint paper, written from personal experience, on the surgery of the labyrinth, which was the first of its kind in this country.

West had built up a large and successful hospital and private practice, and he was under 50 when he decided to retire and leave London. He was a brilliant conversationalist and writer and a connoisseur of good things. He enjoyed golf and badminton, but more than in these was his delight in sailing and motor-boating, especially during the earlier years of his retirement to Flushing, near Falmouth. During the second world war he lived at Sturminster Newton, in Dorset, where he became the medical officer of a local Home Guard battalion. In the first world war he had held a Territorial commission in the R.A.M.C., working at the Camberwell Hospital, where Sir D'Arcy Power was commandant.

After 1945 he moved to South Devon, keeping up his interest in gardening and the countryside. Though his health was not too good, he could still enjoy motoring and twice visited Denmark. He also retained his interest in music, literature, and in reviewing books-even some of the queerest. His writings for the Press were usually anonymous and nearly always on non-professional subjects. West had a keen sense of humour and was an excellent speaker. His first wife died some years after their marriage in 1908. His second wife was Miss Kathleen McCrossan, who was his constant companion to the end. He had no children.

$$
\text { S.R.S. }
$$

\section{GEORGE C. CATHCART, M.D.}

Dr. George Clark Cathcart, who died in a nursing-home at Broadstairs

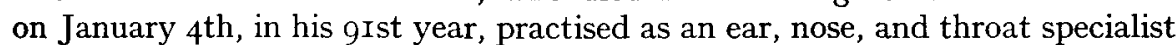
for many years in Upper Wimpole Street and in his day had one of the best consulting practices in the West End of London.

Cathcart belonged to an old Edinburgh family, his elder brother Charles being a well-known teacher of surgery at Edinburgh, and he went to school at Edinburgh Academy and Loretto. He graduated M.A. at Edinburgh in I883, and thereafter went to Australia and back in a sailing ship and was a pupil at Naples of Scarfati, one of the last teachers of the old Italian bel canto, in order to cure a stammer. He returned to Edinburgh to study medicine, graduating M.B., C.M. in I89I and proceeding to M.D. in I908. He came to London as a resident of the Children's Hospital, Great Ormond Street, as did many Edinburgh graduates of those days, and then became resident housesurgeon at the old London Throat Hospital (later amalgamated with the Throat Hospital, Golden Square), to which he was later appointed honorary surgeon. After the amalgamation he became consulting surgeon to the Throat Hospital, Golden Square, and he was also consulting laryngologist to Mount Vernon Hospital, in the days when it was still a hospital for tuberculosis. During and after the first world war he was a member of the Special Aural Board of the Ministry of Pensions. 


\section{Obituary}

In his earlier days Dr. Cathcart was greatly interested in problems of the voice, and at that time his contributions to medical literature were mainly on such subjects as voice production, stammering, and tonsillectomy. It was directly because of this interest that in $\mathrm{I} 894$ he founded the famous Promenade Concerts at the Queen's Hall, London. He insisted that in order to prevent vocal strain the orchestral instruments should be tuned to French pitch and not to the higher concert pitch, as was then usual; and he also insisted that his young friend and "discovery", Henry Wood, should be the conductor of the series of concerts. Then a young bachelor of independent means, Cathcart was quite content, in order to prove his thesis, to lose several thousand pounds in starting the concerts, and when they began to pay their way he gave place to others. In his later days he became more and more interested in deafness and its prevention. He revised and largely re-wrote his friend Hunter Tod's Diseases of the Ear in 1926, and in I93I published a small book, The Treatment of Chronic Deafness, which went into a second edition. Not infrequently the victim of his own kind heart, he was also ever sympathetic towards the unorthodox in medicine-homcopathy, osteopathy, the electrophonoide method of Zünd-Burguet. He had always a current favourite among such methods and their practitioners. $\mathrm{He}$ was an ardent freemason, having been a Past Master of the University of Edinburgh Lodge and a member of Grand Lodge.

Dr. Cathcart never married, but he had many nieces and other relatives to whom he was devoted, and there can have been few men more beloved by more friends in every walk of life.

R.S.S. 